DOI: 10.17951/lrp.2018.37.3.291-301

\author{
LARYSA ZDANEVYCH \\ Khmelnytskyi Humanitarian-Pedagogical Academy \\ https://orcid.org/0000-0001-8387-2143
}

Kateryna KrUtiI

Ternopil Volodymyr Hnatiuk National Pedagogical University

https://orcid.org/0000-0001-5001-2331

\title{
THE “TALKING WALLS” TECHNIQUE AND TIMELY TRANSFORMATION OF EDUCATIONAL SPACE OF PRESCHOOL EDUCATIONAL INSTITUTION
}

\begin{abstract}
The article deals with the scientific approaches towards the educational space. It is noted that the necessary precondition of creating personal space of the child in preschool educational institutions of any property category is the support of a personality-oriented model of interaction between the participants of the educational process. It is stressed that among other modern technologies, which are actively implemented into the practice of work of pre-school educational institutions of Ukraine, the international "Talking Walls" technique should be singled out as the one that gives the child a chance to be the master of their personal space.

The essence of the technology is that the child, receiving the necessary information, has the right to plan their activities, make constructive use of the information resource. In other words, the "Talking Walls" technique is a visualization system of knowledge and the process of immersion of preschoolers and adults into the educational space of kindergarten. Therefore, the joint organization of individual and group partnership with children is a synthesis of organized learning and self-regulated learning (in the broadest sense), in the course of which information (which is freely received from different sources) acquires the status of a subjective (personal) knowledge. The "Talking Walls" technique is not something new and unknown to the Ukrainian colleagues, but it gives the opportunity to look at the educational process from the new angle, to convert it according to the requests of the child's perception and psycho-physiological development.
\end{abstract}

Keywords: educational space of pre-school institution, “Talking Walls” technique, partnership, personality-oriented model 
The present time of preschool education is diverse and interesting. One can select the technique, develop their own innovations, or improve the professional level. Without leaving home or workplace, one can participate in webinars, online training, or distant consultation, and the like. However, considerable groups consist of teachers who are willing to work selflessly and even "reinvent the bicycle", maybe at least one wheel of it, but not to benefit from the experience of others. We should help them to rise to the level that is adequate to today's science, the requirements and demands of the society.

The essence of the problem lies in the fact that in preschool education there is a gap between knowledge and culture as a practical action. Overcoming this gap is the important strategy. The creation of the educational space consists in bridging the gap or building the overcoming, where control is considered as the process of creating of the environment adequate to changes of the society. These changes are inevitable, quick, and real. The changes that take place both in the life of the society and in the life of the individual are the most significant, and, therefore, there are more questions than answers.

If the personal space, in which the child lives, does not meet his or her age requirements, the child feels very uncomfortable, therefore, he or she grows up emotionally and physically immature, incapable of the intimate-personal relationships with the environment, etc. (M. Osorina).

Personal space of the modern preschool child is both physical (body, subject and natural environment, people around, different classes, etc.) and psychological (emotional coloring of life, style of relations of others to the child and between themselves, etc.). A preschooler already quite well controls the body, but the physical and especially psychological interaction with the environment, which makes this world one's "own", is still in the process of forming.

So, the physical space of the preschool child is constantly expanding. The child is taken to the shop, pays a visit to different places, goes to the circus. Together with the parents, the modern preschoolers try to travel; alone they travel around the places they know well, e.g., their kindergarten building, with their families they travel around the city and even countries. The main achievement is learning the space of kindergarten like group room, bedroom, musical and sports halls, staircases and so on.

The psychological space of life of a pre-school age child is characterized by high significance of another adult - teacher, who symbolizes the new status of the child, on whom the emotional well-being of the individual child and the people that surround him/her depends. Very often a preschooler is ready to introduce the teacher to his personal space, put him/her next to the mother.

Personal space, according to M. Osorina, has a complex system of coordinates that the baby develops from early childhood, primarily on a subconscious level 
(Osorina 2000, p. 288). Spatial coordinates (familiar places, ways, objects, trees, etc.) help the child to navigate the place and to implement their physical activity, to test themselves in this respect; social coordinates (norms, rules, regulations, prohibitions, rituals, etc.) mainly help to understand the life collisions, the specific situations in which the child is a participant. Spiritual-moral coordinates (hierarchy of values of the surrounding world, patterns and precedents of human interaction, forms of their behaviour, and the like) help the preschooler to understand the relationships between adults. Emotional coordinates of the personal space of the child is the family and home. It is the family, even if it consists of the minimum number of members, that introduces the child with the past and the future. For the full value development of the preschool child, the home, in which there is the child's personal place (separate room, place for toys, bookshelf, etc.), is needed.

In our opinion, essential condition for establishing the personal space of the child in preschool educational institutions of any form of ownership is the reliance on the personality-centred model of interaction between the participants of the educational process.

Scientists for the first time formed the order and for the first time they created the creative team of scientists - representatives of different professions: psychologists, designers, architects to develop the concept of building the developmental environment for the organization of life of children and adults in kindergarten. In the prepared concept, the principles of person-oriented model of educational environment in pre-school educational institution were defined. It was reproduced in the principles of formation of subject-developing environment presented in the concept of V. Petrovskyi, L. Klarina, L. Strelkova (1996, pp. 100-109).

In the modern preschool educational institution, these principles can be carried out (and already are) only partially. Innovative architectural projecting, new design, industrial products (equipment, furniture, toys, etc.) of the new generation will be required in the preschool education. Tangential to the problem of our article is the principle of combining usual and unusual elements in the aesthetic organization of the environment, which assumes such an approach to the design of interior spaces, which would be used as a reproduction of classical works, and the works that encourage children to think, to fantasize. For example, it is advisable to decorate the room "Magic Paints" with optical mixing of colour lighting when changing colour filters. This kaleidoscope allows creating the dynamics of colour perception of the subject-developing environment, its changes in accordance with the program of development of colour sense, the culture of colour perception of the environment. In the modern pre-school educational institutions, the design of interior spaces using natural materials is commonly used. It makes a significant reversion to the standard layout of the rooms, creates a special, unique image of the kindergarten. 
Among the modern technologies that are being actively introduced in the practice of work of pre-school educational institutions of Ukraine, we should single out the international "Talking Walls" technique as the one that provides children with the opportunity to be the absolute master of his or her personal space. In mass media and in the Internet, one can find information that this technique was introduced to the colleagues from Estonia. We should mention that this technique of Estonian teachers is created for preschoolers, but we cannot confirm that it is of their authorship. The technology is spread in many other European countries, it is widely used not only by teachers. Therefore, we want to describe the most attractive and efficient qualities of this technique for early childhood education.

\section{BRIEFLY ABOUT THE EMERGENCE OF THE TECHNIQUE}

Beautifully illustrated children's book by Margy Burns Knight entitled Talking Walls (illustrated by Anne Sibley O'Brien) introduces young readers to different cultures by exploring the stories of walls. One of such stories is devoted to the cave of Lascaux in France (in 1940) in which children found beautifully painted horses, bison and antelopes. It is known that wall paintings, for example, in the cave of Lascaux, are over seventeen thousand years old. On the walls of the caves there were painted animals for special hunting and religious ceremonies. The adventures of kids from this book inspired some people to use the idea of the story in music, film, graffiti and interior design. Therefore, Talking Walls ${ }^{\bullet}-$ the multimedia resource for children, pedagogues, adults, people with disabilities and organizations interested in history - was created. It is designed to promote interest particularly in heritage sites, which cover educational, cultural, artistic, social and historical aspects.

Talking Walls satisfies many requirements and covers such topics of educational programs as sciences, technologies, reading and writing, engineering, art, design, mathematics (STREAM - education, one can read more at: http://ukrdeti.com/ category/stream-osvita-doshkilnikiv/). Talking Walls is a popular international resource where one can find ideas for every taste and for realization of any purpose.

\section{THE ESSENCE OF THE “TALKING WALLS” TECHNIQUE}

The book Talking Walls can be the source of inspiration and creativity for a child. The essence of the "Talking Walls" technique is in the fact that the child, receiving the necessary information, has the right to plan their activities, make constructive 
use of the information resource. In other words, this technique is a visualization system of knowledge and the process of immersion of preschoolers and adults into the educational space of kindergarten.

It should be noted, there cannot be uniform requirements or recommendations regarding the establishment, functioning, frequency of replacing the images on the "talking wall". Introducing the offered ideas, one should, first of all, critically review the possibilities of withdrawal of methodological clutter of space of both preschool educational institution and specific group rooms, locker rooms, etc. (announcements that nobody is interested in; the list of children with the mentioned height and weight for the 1 September, when it is December now; notification to parents about the need to bring 3 rolls of toilet paper and the like).

The technique can be used both to inform all participants of educational process (children, parents, teachers) or it can be targeted only at preschoolers.

Why the wall? Under the modern conditions, the kindergartens adopt new design standards, there are fewer stands, which "do not attract attention" and do not carry relevant information. The priorities are movable billboards, exhibitions and much more. Therefore, there is one wall that can attract attention without disturbing the inner harmony of the space of preschool educational institution. Additionally, it may perform a developing function.

How to make the walls really "talk"? As to the choice of the wall, the best of all would be a big wall on the first floor. If we are talking about all the participants of the process, the specifics of the kindergarten involves the use of "Talking Walls" most often in one or two fixed places, where often there are children and adults (advertising, information, awards and the like). The wall may consist of several informational (periodically changing) areas.

During the process of designing the wall for adults, one need to consider that the image should be placed on the contrasting background and be visible at the distance of one to two meters. The text should be printed on the printer or written in simple (without decorations) block or capital letters. It is desirable that the handwritings, the fonts and possibly the sizes of the letters were different.

One needs to strive to ensure that exposure was not monotonous. It is better that it consists of vague inscriptions displayed on the walls, which kids love to make, and which later they love to read. If the financial abilities of preschool educational institutions allow repainting the wall pretty often, learners can write right on the wall.

There is, however, simpler and cost-efficient way of implementation of the above-mentioned technique. It is also less damaging to walls. One can simply hammer a few nails into the wall or attach small hooks on which posters made of heavy paper, flags, balloons or frames with flowers, letters with text can be hanged. 
It is also possible to use ceiling tiles that can be decorated with leaves, which later can be replaced with something else ("the effect of talking ceiling"). What is more, this "wall" can be easily moved from one place to another, in other words, it can "travel" around the buildings of the kindergarten. To use the proposed technique in the work with pre-school children, we need to consider certain peculiarities.

One of the pedagogical ways of organization of important educational events in the life of preschool staff and individuals is the technique of event approach. The idea of the event approach is borrowed from the pedagogical system of A. Makarenko, who noted that important and exciting events that cause positive emotional response in the minds of children of all ages are of great significance.

The essence of educational event is that special conditions for children's actions are organized. The obtained experience turns into the means to achieve a new, higher goal. We should mention that any of the participants of the educational event is a real participant and not a spectator - each person and his/her activities and experiences is important.

The construction of the educational process by the event principle will make the lives of children in kindergarten more interesting and the educational process - motivating.

The basis of implementation of the educational event for all participants of the educational process are the following approaches:

- happy event in social life of the society or the holiday (e.g., Day of the Heavenly Hundred Heroes, Victory Day over Nazism in World War II, etc.);

- events that generate the sense of nationality of the child (e.g., Europe Day);

- traditional festive family, society and state events (e.g., New Year, Mother's Day).

Apart from the above-mentioned aspects, we should consider the approaches to implementation of the "Talking Walls" technique in preschool educational institutions.

As we know, the person determines itself in space, reacting, primarily, to the complex of audiovisual stimuli. According to E. Kudriavtseva and T. Volkova, the children, getting into unknown or unfamiliar environment, look around, highlighting the signals, which later become decisive for their patterns as far as children's behaviour and reactions are concerned (Kudriavtseva, Volkova 2013, p. 40). The images that are used in the space of preschool educational institution, can even be works of art with their own functional activity (advertising, campaigning and training) and with accordingly strengthened emotional component that "speaks" directly to the viewer, taking into account his or her psycho-physiological characteristics.

We can formulate several principles for the selection of images (posters, drawings, paintings, photos, announcements, etc.) to design "talking walls" (adapted material of E. Kudriavtseva): 
- correspondence of what is depicted to the age-specific perception and experience of perception of visual means (the contents of the whole analysis and interpretation; number, size, brightness of the components);

- availability of the national/cultural component in the image that attracts the attention/interest and that is understandable for children and interesting to talk about with teachers/parents (the initiators of such conversations can be both children and adults);

- multi-level structure of what is depicted both at the contextual and emotional levels;

- availability of the text on the image is optional;

- the image should be available for the target group as the element of equipment (Kudriavtseva, Volkova 2013, p. 40). If the images match the mentioned principles, they can be used on the walls for the development of observation and logical thinking of preschoolers.

One should also follow the recommendations of designers about the placement of photographs, paintings, drawings, posters or murals. Illustrated materials should provide the equivalent reflection of information that is inaccessible to sensory perception through the time distances, abstractions, details, etc.

First of all, it should be remembered that the wall must be a background, which complements the image, rather than a competing factor. If the composition of various-sized objects is created, then the smaller images should be equivalent in size to the large ones (several small images + one big). For the harmonious perception of the composition, its size should be about one third of the size of the background. It should be added that symmetric compositions are always a good idea in the interior of the kindergarten building, but asymmetry provides more emotional experience.

With reference to "talking walls", let us remember about the statement of the outstanding teacher of our time V. Shatalov about "the effect of pickled cucumbers" and the walls which may lead to it: if fresh cucumbers are placed in brine, they have to become pickled, whether they like it or not. The very same is true regarding the child: if the child spends time in the neat, tidy, aesthetically designed environment where everything around is pedagogically reasoned, it affects the child's attitude to the kindergarten and to itself; if the child spends time in different surroundings, then it is very likely that it will grow different as well.

Every day spent in kindergarten involves experiencing various feelings, emotions and different kinds of activity. "Talking walls" are the walls thanks to which preschoolers communicate with one another, convey information, share knowledge. The walls allegedly "provoke" the children, and sometimes even force them to engage in researches, experiments, search for new information. Maybe not all children will participate in the activity, but involuntarily they will certainly adhere to it. 
As an example we will demonstrate studying of the educational event "The World of Childhood in Photos of Centuries", the result of which was later displayed on the "talking walls". Its objective was to involve children in the development of the project, working out of educational program for parents, educators, psychologists, social pedagogues, librarians, employees of exhibition halls, and students of humanitarian specialities.

Let us enumerate the principles of selection of photos. When selecting the photos, we try to show the diversity of the world of children that belong to different historical periods, ethnic cultures, social strata. This diversity is especially reflected in children's toys, clothes, or items of everyday life. First of all, one should pay attention to the following aspects: who is in the photo (boy, girl, group of children); is the child alone (or with adults, other children); where was the picture taken (at home, in the studio, in the street); is the child holding anything in his/her hands (a toy) or is it anything next to him/her; what is the child wearing (type of clothes conditioned by different circumstances, e.g., bad weather, war, illness, etc.).

When describing the photo, it is desirable to mention: 1) the collection this photograph comes from; 2) the date of taking the picture; 3 ) location (according to the owners); 4) name/age of the child depicted in the picture; 5) toys that are shown in the picture and the material they are made of (if the narrator remembers it); 6) the place the toys come from (origin) - whether it is a domestic product, imported (country specification), or hand-made (if so, who made it); 7) narrator's spontaneous comments. Additionally, there are some questions which should also be taken into account, e.g., 8) what do you remember when you start to look at your old photos? 9) how often do you look at old family photos at home with children? 10) do you create a family newsletter using a photographic collage?

We can use photos of children during: reading of children's literature; composing the story based on pictures (in this case on photographs); introduction to the environment (children of other nationalities, their toys, clothes); drawing a family tree (little father, grandfather, etc.); studying of great people's lives (first of all, countrymen); adaptation of the child to a preschool educational institution.

Thus, the projects that were created on the basis of the use of social networks (https://www.pinterest.com/), namely boards with the title "Children and old toys", which consisted of over 700 photos of children with toys, were of interest to us. Therefore, specific approaches are the basis of the implementation of the educational event that has its reflection on the wall for preschoolers. We are going to explain them.

Defining "The Wall Which Will Talk", we conventionally (or clearly defining the boundaries) divide it into 3-4 parts. More parts are not needed, because the information for the child will be lost in the background of other images. So, one 
part of the wall can be devoted to events that are remote in time and organized in advance, for example, they can be connected with:

- happy events of the moral life (e.g., birthdays);.

- phenomena of the environment (days of water, land, animals, or specifically - day of meerkat, i.e. the animal, which is relatively unknown among children and adults);

- world of art and literature (days of poetry, children's book, theatre);

- the most important profession (days of educator, teacher, etc.).

Another part of the wall can be called "Perspective of growth: child, parents, educators". The perspective of growth is understood as the amount of information that any participant of the educational process can share. The information can be in any available form: photo, book which was read, travel photo album, projects that children present during the topical week. The example of integration of techniques can be the Danish "Free Yourself from Persecution" method ("Kindergarten Without Violence"), where the main characters are teddy bears and each child has his/her own toy (more information at: http://ukrdeti.com/datskametodika-zvilnitis-vid-ckuvannya-dityachij-sadok-bez-nasillya/). There is also one big teddy bear which is taken home for the weekend by each family. Parents and child should remember about the teddy bear when planning their weekend. They should spend time together (go with the whole family, including the bear, to the zoo, make a cake, ride the 4 -wheeler, etc.), and then make a photo story, which later will be presented by the children. Next, photo stories from Sunday's travelling of the bear are placed on the wall.

The next part of the "talking wall" composition is displayed on the day, when there is one or another educational event, for example: after the conducted lesson there appear the tasks for consolidation: drawing and coloring, funny puzzles, books, encyclopaedias, mnemotables, etc. Thus, during the planning of the day, the educator together with children uses different symbols: pictures, rebuses, tasks, riddles, as if revealing the secret of the activity that will take place today. It is appropriate to use on the wall the elements of edutainment - "Education as Entertainment" (the article about the phenomenon of edutainment can be read at: http://ukrdeti.com/edyutejnment-navchannya-yak-rozvaga/).

The content of this part of the "talking walls" can be used by the child when moving from one group to another. For example, the plan of making things using Lego bricks can be useful in the area of construction and the description of the algorithm of experience implementation - in the experimental area.

Additionally, the part of the sensor wall in the group room can be made sectional. The information field can be both classic and figurative-associative. Figurative-associative part allows one to imagine fairy tale characters, fairy tale 
stories, magical items, buildings, palaces and towers. Coloring of additional elements provides the opportunity for variability and imagery, which plays an important role in the development of sensory abilities of preschoolers. The children themselves can participate in the formation and development of the informational field of the sensor wall. What is more, there are a number of stands which can be invented by children. For example: the stand called "House" gives a wide field of activity to represent characters of the House - the children's fairy tale- as well as to explore other materials of children's literature.

The next example is the "Fir tree" stand which is perfect for decoration. Children can make paper Christmas decorations by themselves, and then decorate the stand. Similarly, puppet theatre can be built by children. It will not be superfluous to remind that these stands can easily be subjected to wet cleaning, they are not damaged and, therefore, they can be quickly replaced with another motif.

To sum up, the joint organization of individual and group partnership with children is a synthesis of organized learning and self-regulated learning (in the broadest sense), in the course of which information (which is freely received from different sources) acquires the status of a subjective (personal) knowledge. The "Talking Walls" technique is not something new and unknown to the Ukrainian colleagues, but it gives the opportunity to look at the educational process from the new angle, timely to convert it according to the requests the child's perception and psycho-physiological development.

\section{REFERENCES}

Кудрявцева, Е.Л., Волкова, Т.В., 2013, Методические рекомендации по использованию изображения в обормлении образовательного пространства русскоязычного образовательного иентра. Рига: RetorikaA.

Осорина, М.В., 2000, Секретный мир детей в пространстве мира взрослых. Санкт-Петербург: Питер.

Петровский, В.А., Кларина, Л., Стрелькова, Л., 1996, Субъектность: новая парадигма в образовании. «Психология детства», Т. 3.

http://ukrdeti.com/datska-metodika-zvilnitis-vid-ckuvannya-dityachij-sadok-beznasillya/ [access: 10.02.2017].

http://ukrdeti.com/category/stream-osvita-doshkilnikiv/ [access: 20.02.2017].

http://ukrdeti.com/edyutejnment-navchannya-yak-rozvaga/ [access: 06.03.2017].

https://www.pinterest.com/ [access: 26.02.2017]. 
TECHNIKA „ŚCIANY, KTÓRE MÓWIĄ” I CZASOWA TRANSFORMACJA PRZESTRZENI EDUKACYJNEJ PRZEDSZKOLA

\begin{abstract}
Abstrakt: W artykule przedstawiono naukowe podejścia do projektowania oświatowego obszaru przedszkola. Zaznaczono, że koniecznym warunkiem stworzenia osobistego obszaru dziecka w edukacji przedszkolnej, o dowolnej formie własności, jest oparcie jej o model współdziałania między uczestnikami procesu oświatowego. Zaakcentowano, iż nowoczesne technologie aktywnie wprowadzono do praktyk w przedszkolach Ukrainy, szczególnie tę o charakterze międzynarodowym, nazywaną „ściany, które mówią” (tytuł oryginalny „Talking Walls”). Istota tej techniki polega na tym, że dziecko, otrzymując konieczną informację, ma prawo i możliwość zaplanować swoją działalność, wykorzystując przy tym posiadane zasoby w sposób konstruktywny. Innymi słowy, technika „ściany, które mówią” jest systemem wizualizacji wiedzy oraz procesem zanurzenia przedszkolaków i dorosłych w system oświatowy przedszkola. Metoda ta nie jest obca ukraińskim nauczycielom. Pozwala ona na nowe postrzeganie systemu oświatowego oraz jego bieżącą modyfikację w kierunku rozwoju psychofizycznego dziecka.
\end{abstract}

Słowa kluczowe: oświatowy obszar przedszkola, technika „ściany, które mówią”, partnerstwo 